Research Article

\title{
Optical Properties Comparison of Carbon Nanodots Synthesized from Kangkung (Ipomoea aquatica) with Deep Frying and Roasting Techniques
}

\section{Wipsar Sunu Brams Dwandaru ${ }^{1, a}$, Fika Fauzi 1,b, Dyah Silviana Sari 1,c, Emi Kurnia Sari 1,d,", Iman Santoso ${ }^{2, \mathrm{e}}$, and Haris Suhendar ${ }^{2, \mathrm{f}}$}

\footnotetext{
${ }^{1}$ Physics Education Department, Faculty of Mathematics and Natural Sciences, Universitas Negeri Yogyakarta, Jalan Colombo No 1, Karangmalang, Yogyakarta 55281, Indonesia

${ }^{2}$ Department of Physics, Faculty of Mathematics and Natural Sciences, Universitas Gadjah Mada Sekip Utara Bulaksumur, Yogyakarta 55281, Indonesia

e-mail: awipsarian@uny.ac.id, ${ }^{b}$ fika.fauzi@uny.ac.id, ${ }^{c}$ dyah.silviyana2015@student.uny.ac.id,

d kurniasariemi@gmail.com, ${ }^{\mathrm{e}}$ iman.santoso@ugm.ac.id, and ${ }^{\mathrm{f}}$ haris.suhendar@mail.ugm.ac.id

* Corresponding Author
}

\begin{abstract}
Carbon nanodots (Cdots) have many unique properties such as luminescence that can be utilized in various fields. The purposes of this study are to synthesize Cdots from kangkung (Ipomoea aquatica) through frying and roasting techniques and compare the optical properties of the Cdots using UV-Vis, PL, and FTIR. Three stages of synthesizing process of Cdots, i.e.: preparing the kangkung powder (root, stem, leaf) and synthesizing the Cdots through frying and roasting techniques. Each part (root, stem, and leaf) was heated in an oven at $250^{\circ} \mathrm{C}$ for 2 hours and mashed into powder. The frying method was done by frying $15 \mathrm{~g}$ of the powder in $120 \mathrm{ml}$ oil for 5 minutes at $88{ }^{\circ} \mathrm{C}$, filtered, and dissolved in $n$-hexane. In addition, the roasting method was done by frying the powder without oil as much as $15 \mathrm{~g}$ for 5 minutes, dissolved in $120 \mathrm{ml}$ of distilled water, and then filtered. The UV-Vis characterization showed one absorbance peak for Cdots via frying and roasting techniques at $293 \mathrm{~nm}$ to $296 \mathrm{~nm}$ and $262 \mathrm{~nm}$ to 282 $\mathrm{nm}$, respectively. The Cdots through frying and roasting techniques produce red and green luminescence, respectively. The FTIR characterization showed the presence of $C=C$ and $C=O$ functional groups, which are the core and surface state of the Cdots by frying technique, while the samples via roasting technique showed only the core. It can be concluded that the Cdots samples obtained from frying and roasting methods have different optical properties. The frying method produces Cdots with longer wavelength at the absorbance peak in the UV-Vis test compared to the roasting method. Moreover, the frying and roasting methods produce different color luminescence.
\end{abstract}

Keywords: Cdots, kangkung, frying technique, roasting technique

\section{Perbandingan Sifat Optik Carbon Nanodots Berbahan Dasar Tanaman Kangkung (Ipomoea aquatica) dengan Teknik Penggorengan dan Sangrai}

\begin{abstract}
Abstrak
Carbon nanodots (Cdots) memiliki berbagai sifat unik yang bermanfaat seperti luminesens sehingga dapat dimanfaatkan dalam berbagai bidang. Tujuan dari penelitian ini adalah mensistesis Cdots berbahan dasar tanaman kangkung (Ipomoea aquatica) dengan teknik penggorengan dan sangrai, serta
\end{abstract}


Jurnal Penelitian Fisika dan Aplikasinya (JPFA), 2019; 9(2): 123-131

membandingkan sifat optik Cdots menggunakan UV-Vis, PL, dan FTIR. Sintesis Cdots dibagi dalam tiga tahapan, yaitu: membuat serbuk tanaman kangkung (akar, batang, dan daun) dan mensintesis Cdots dengan teknik penggorengan dan sangrai. Pertama, tanaman kangkung dipisahkan menjadi bagian akar, batang, dan daun. Setiap bagian dipanaskan menggunakan oven selama 2 jam pada suhu $250{ }^{\circ} \mathrm{C}$ dan ditumbuk menjadi serbuk. Metode penggorengan dilakukan dengan menggoreng $15 \mathrm{~g}$ serbuk setiap bagian kangkung dalam $120 \mathrm{ml}$ minyak goreng selama 5 menit pada suhu $88^{\circ} \mathrm{C}$, kemudian disaring dan dilarutkan dalam $n$-hexana. Sedangkan metode sangrai dilakukan dengan menggoreng serbuk tanpa minyak sebanyak $15 \mathrm{~g}$ setiap bagian kangkung selama 5 menit, kemudian dilarutkan dalam $120 \mathrm{ml}$ aquades dan disaring. Sampel Cdots dari kedua teknik ini dikarakterisasi menggunakan UV-Vis, PL, FTIR. Karakterisasi UV-Vis untuk teknik penggorengan dan sangrai menunjukkan satu puncak absorbansi, masing-masing pada rentang $293 \mathrm{~nm}-296 \mathrm{~nm}$ dan $262 \mathrm{~nm}-282 \mathrm{~nm}$. Karakterisasi PL untuk sampel dengan teknik penggorengan dan sangrai menghasilkan satu puncak intensitas, masing-masing pada rentang $620 \mathrm{~nm}-750 \mathrm{~nm}$ dan $400 \mathrm{~nm}-600 \mathrm{~nm}$. Sampel dengan teknik penggorengan menghasilkan pendaran warna merah sedangkan sampel dengan teknik sangrai menghasilkan pendaran warna hijau. Karakterisasi FTIR untuk teknik penggorengan menunjukkan gugus fungsi $C=C$ dan $C=O$ yang merupakan core dan surface state dari Cdots, sedangkan teknik sangrai hanya menunjukkan core saja. Metode penggorengan menghasilkan panjang gelombang pada puncak absorbansi yang lebih besar daripada metode sangrai. Selanjutnya, kedua metode menghasilkan emisi pendaran yang berbeda.

Kata Kunci: Cdots, tanaman kangkung, teknik penggorengan, teknik sangrai

PACS: 78.67.-n, 78.67.Hc

(C) 2019 Jurnal Penelitian Fisika dan Aplikasinya (JPFA). This work is licensed under CC BY-NC 4.0

Article History: Received: August 23, $2019 \quad$ Approved with minor revision: November 21, 2019

Accepted: December 6, 2019 Published: December 31, 2019

How to cite: Dwandaru WSB, et al. Optical Properties Comparison of Carbon Nanodots Synthesized from Kangkung Plant (Ipomoea aquatica) with Deep Frying and Roasting Techniques. Jurnal Penelitian Fisika dan Aplikasinya (JPFA). 2019; 9(2): 123-131. DOI: https://doi.org/10.26740/jpfa.v9n2.p123-131.

\section{INTRODUCTION}

One of popular technologies which is being developed in the $21^{\text {st }}$ Century by several countries around the world is nanotechnology. Nanotechnology is the engineering or creation of materials, functional structures, and devices on nanometer scales [1], i.e.: $1 \mathrm{~nm}$ to $100 \mathrm{~nm}$. This trend is believed to be in line with the increasing awareness of the society with environmentally-friendly technology, namely the higher expectation of the society to the eco-friendly or green product commodities to ensure that the product is good for humans and the environment [2].

One of product produced through nanotechnology is carbon nanodots (Cdots) [3]. Cdots are made of carbon elements that are available and generally non-toxic in nature [4]. Some characteristics of the Cdots are namely having a size of $1 \mathrm{~nm}$ to $10 \mathrm{~nm}$, an amorphous structure, and spherical shape $[5,6]$. The discovery of the Cdots has become popular topic, and they have been widely studied in the world due to their their unique size and benefits [7]. Cdots have potentials to replace semiconductor quantum dots and also can be used in a variety of applications such as biomedical imaging, analytic detection, fullcolor display, and light-emitting devices $[8,9]$. One prominent application of the Cdots is in biological application because Cdots can be made of organic materials that are easy to find and available in nature [10]. 
At the moment, Cdots based on environmentally friendly technology are still being under development, especially in Indonesia [11]. As Indonesia has diverse organic materials of plants and animals, it is believed to have huge potentials as the carbon sources of Cdots. In previous studies, carbon sources that have been used for synthesizing Cdots include candle soot [12], tobacco leaf [13], orange peel [14], banana juice [15], and so forth. Despite the fact that there have been several carbon sources to produce Cdots as mentioned above, there is still a need to synthesize Cdots from other carbon sources to enrich the possibility of producing Cdots. In this study, the synthesis of Cdots would use kangkung plants (Ipomoea aquatica) are used as the alternative carbon source of Cdots. Kangkung have roots, stems, fruits, flowers, and seeds. Kangkung plants are popular in tropical countries like Indonesia as green vegetables because they have a chlorophyll structure [16]. In addition, kangkung plants are easy to obtain, and the utilization of this plant in the area of technology needs to be explored. Furthermore, kangkung plants have never been utilized as the alternative carbon source for Cdots material.

Innovation in synthesis of Cdots is expected to produce Cdots materials with superior, efficient, and satisfying properties [17]. The innovation is mainly from the methods used in producing the Cdots. Different synthesis methods can produce different amount of carbon, oxygen, nitrogen, and other functional properties of the Cdots. In addition, it causes differences in carbogenic core and surface structures of the Cdots [18].

To date, the simplest methods that are used in the synthesis of Cdots are hydrothermal and microwave [1]. These methods can produce different characteristics of the Cdots. Therefore, it is interesting to study new methods in the synthesis of the Cdots using frying [19] and roasting. These methods are simple, effective, and inexpensive, and can produce Cdots on a large scale; these methods do not require sophisticated equipment and hazardous chemicals during the synthesizing process.

Hence, the objectives of this study are to give information about preparing, synthesizing, and characterizing Cdots made of kangkung plants through frying and roasting techniques. The Cdots are characterized using UV-Vis spectrophotometer, photoluminescence (PL), and Fourier Transform Infrared spectroscopy (FTIR) to compare the optical properties of the Cdots by frying and roasting technique.

\section{METHOD}

\section{Preparation of kangkung powder}

Preparation of making kangkung powder was started by cleaning the plants by separating the parts of the plants based on their roots, stems, and leaves. Then, each part of kangkung was heated in an oven at $250{ }^{\circ} \mathrm{C}$ for 2 hours and then mashed using a mortar into powder. The kangkung powder consists of stem powder, root powder, and leaf powder.

\section{Synthesis of Cdots by frying technique}

Synthesis of C-dots by frying technique was done by frying $15 \mathrm{~g}$ of stem powder in $120 \mathrm{ml}$ cooking oil for 5 minutes at $88{ }^{\circ} \mathrm{C}$. Then, the sample was filtered using a filter paper number 40 to separate the solution and the remaining powder. $5 \mathrm{ml}$ of the solution was mixed with $30 \mathrm{ml} \mathrm{n}$-hexane and stirred until homogenous. The same procedures were conducted for leaf and root powders.

\section{Synthesis of Cdots by roasting technique}

Synthesis of C-dots by roasting technique was done by roasting $15 \mathrm{~g}$ of stem powder for 5 minutes. The roasted step powder was then mixed with $120 \mathrm{ml}$ of distilled water. It was then stirred until homogenous and filtered to separate the 
solution and the remaining powder. Then, the same procedures were conducted for leaf and root powders.

\section{Characterizations}

\section{UV-Vis spectrophotometer}

The UV-Vis spectrophotometer was used to determine the wavelength of Cdots at maximum absorbance peak. The range of the wavelengths was selected from $200 \mathrm{~nm}$ to 800 $\mathrm{nm}$. This characterization was done by preparing $5 \mathrm{ml}$ of each sample solution. The n-hexane and distilled water were used for blank solutions in this characterization.

Photoluminescence (PL)

The PL characterization was used to determine the emission of Cdots. The result of this characterization shows the wavelength of the emission at maximum intensity. This characterization was done by preparing $5 \mathrm{ml}$ of each sample solution, and there is no need for blank solution.

Fourier Transform Infrared (FTIR)

FTIR was used to determine the functional groups contained in the Cdots solutions. The result of this characterization shows a graph of $\%$ transmittance vs. wave number. The wave number indicates the functional groups contained in the sample. This characterization was done by testing the C-dots solution as the sample.

\section{III.RESULTS AND DISCUSSION}

Cdots have been synthesized from kangkung with two different techniques, i.e.: roasting and frying techniques. The Cdots solutions by frying and roasting techniques are given in Figures 1 and 2, respectively. Based on Figure 1, the Cdots solution from the stem of kangkung by frying technique is turbid. This indicates that more Cdots are formed from stem of kangkung than other parts which have clear solutions [1]. Moreover, the Cdots solutions by frying technique are generally clearer compared to the Cdots solution made by roasting technique. It can be observed that the Cdots solutions by roasting technique are transparent brown color solution (Figure 2). Therefore, it may be deduced that different techniques in producing Cdots produce different color solutions. This may be affected by the amount of Cdots contained in the samples. Moreover, this also indicates that the roasting technique produces the most Cdots.

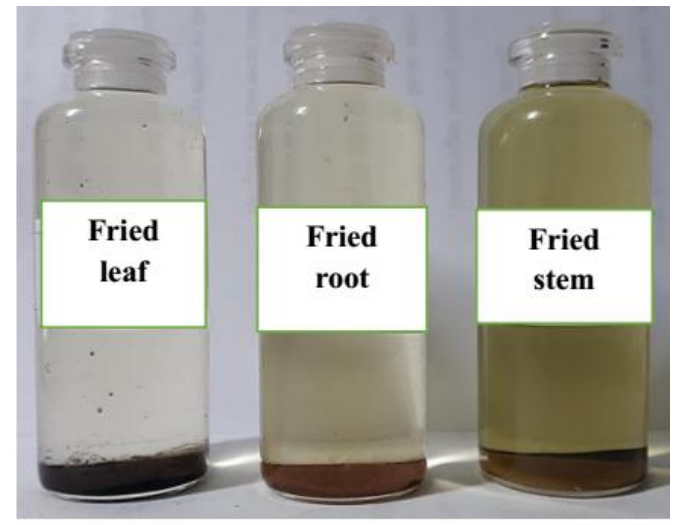

a)

b)

c)

Figure 1. The Cdots Solution via Frying Technique from (a) Leaf, (b) Root, and(c) Stem

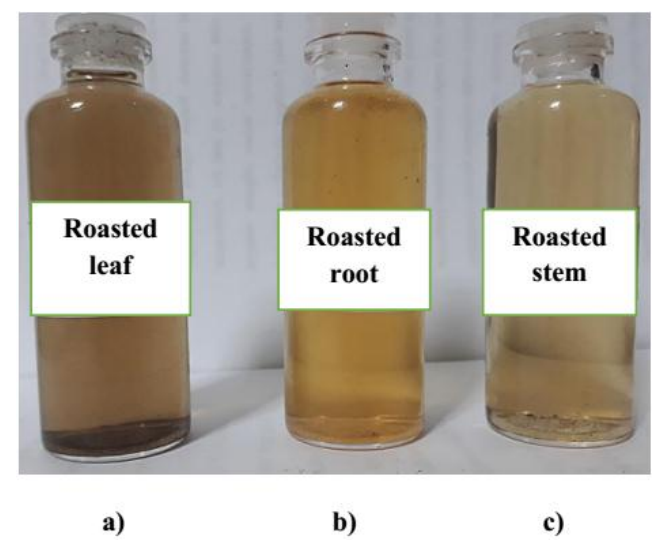

Figure 2. The Cdots Solution via Roasting

Technique from (a) Leaf, (b) Root, and (c) Stem

In this study, the Cdots solution is characterized using UV-Vis. The UV-Vis results show the absorbance patterns of Cdots by frying technique presented in Figure 3 . The Cdots samples from leaf, stem, and root have one absorbance peak. The peak is at the range of 293-296 nm. This is in accordance to the 
study that Cdots generally show optical uptake on the wavelength of UV with the tail extending on the wavelength of visible light $[15,20]$. Furthermore, the peaks indicate the core of Cdots [21]. Based on Figure 3, the stem of kangkung provides the highest absorbance peak. The higher the absorbance value, the more Cdots will be produced, indicating that the highest production of Cdots is from the stem of kangkung plants.

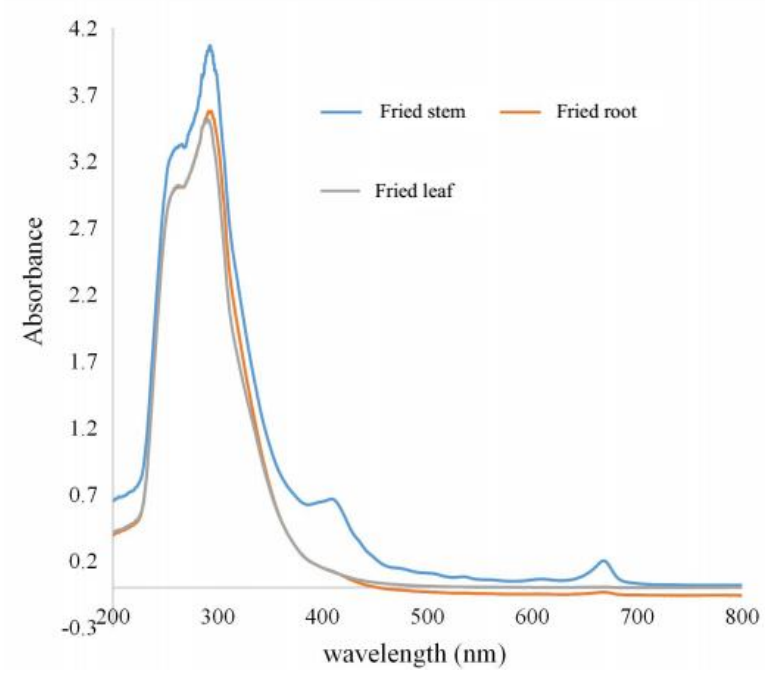

Figure 3. The Characterization Results of the

Cdots by Frying Technique using UV-Vis

The results of UV-Vis test for Cdots by roasting technique is shown in Figure 4. The Cdots samples from the leaf, stem, and root have one absorbance peak in the ranges of 262-282 $\mathrm{nm}$. This is in accordance with the study that shows the absorbance peak of Cdots is at $260-360 \mathrm{~nm}$ [18]. As in the previous result, the samples have one absorbance peak that shows the core of Cdots [21]. Moreover, the root of kangkung has the highest absorbance peak. This shows that the production of Cdots via the roasting technique is mostly produced from the root of kangkung plants.

The frying and roasting techniques produce the Cdots solutions with one absorbance peak in different ranges of wavelength. The Cdots by frying technique has longer wavelength at the absorbance peak compared to the Cdots by roasting technique. The results from the UV-Vis tests show that the absorbance peaks of the Cdots via frying and roasting are obtained at 293-296 $\mathrm{nm}$ and 262-282 nm, respectively. This clearly shows that the absorbance peak of the Cdots by frying is located at longer wavelength compared to the Cdots via roasting. The absorbance peak is attributed to the $\pi \rightarrow \pi^{*}$ electronic transitions or excitation of the core of Cdots [15,21].

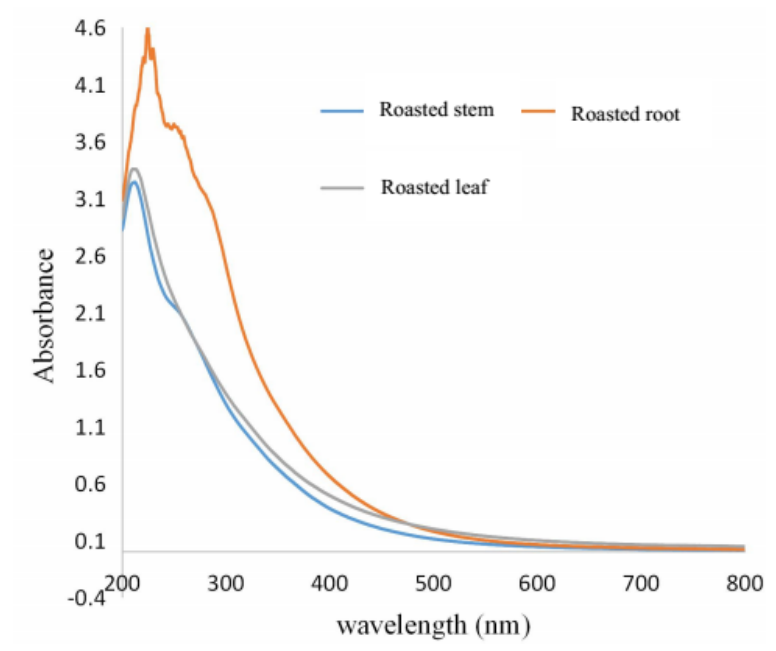

Figure 4. The Characterization Results of the

Cdots by Roasting Technique using UV-Vis

The next characterization was using PL to determine the emission of the Cdots. The PL detects the electronic transitions from the excitation to ground states and show it on a graph of intensity vs. emission wavelength. The result of PL for the Cdots by frying technique is presented in Figure 5. The samples of Cdots by frying technique have two intensity peaks in the ranges of 674-677 $\mathrm{nm}$ and 500-510 nm, respectively. This means that the Cdots solution emits red and green colors, respectively $[15,22]$. According to $\mathrm{Li}$ et al the red emission indicates the porphyrin structures contained in the sample [22], which is the surface state of the Cdots and the green emissions indicates the core of the Cdots. Based on Figure 5, the Cdots made of the stem of kangkung has the highest intensity peak of 
emissions showing that the electronic transition from the excited to ground states are mostly produced by the stem of kangkung [15]. This is in accordance with the results of UV-Vis tests.

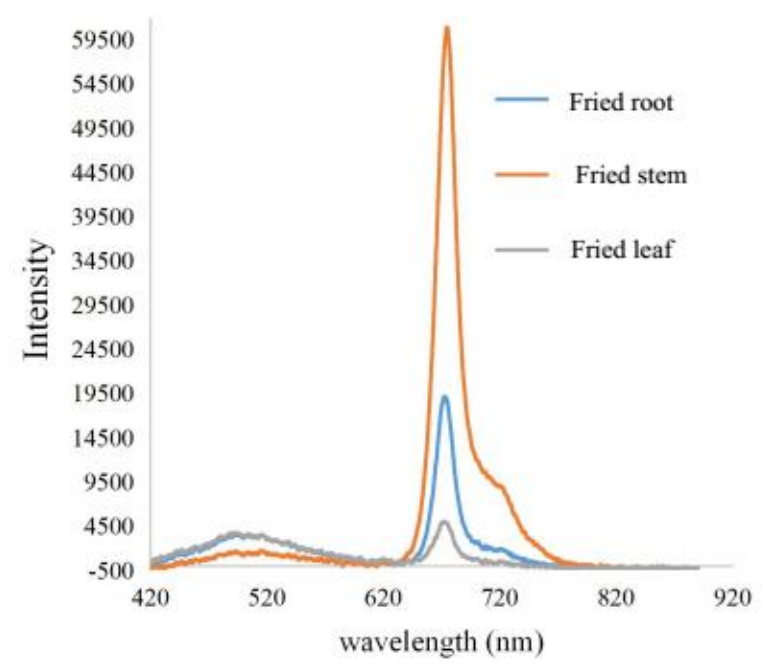

Figure 5. The Characterization Results of the Cdots by Frying Technique using PL

The results of the PL characterization for the samples of Cdots by roasting technique are presented in Figure 6. The Cdots have an intensity peak in the range of 511-519 nm, so that the Cdots emit green color [15,21,23,24]. Based on Figure 6, the highest intensity peak of emission is obtained by Cdots from the leaf of kangkung plants which indicates that the particles of Cdots from the stem of kangkung are mostly the transition from the excited to ground states [15]. The frying and roasting techniques produce different color emissions. The Cdots produced by frying technique emit red and green colors, while the Cdots by roasting technique only emit green color; different synthesis methods will produce different characteristics of the Cdots produced. The difference in the procedure brings forth different Cdots properties, one of which is the luminescence color.

The final characterization was using FTIR to determine the functional groups contained in the Cdots. The result of FTIR shows the relation of transmittance and wave number. Every functional group has different wave number that depends on the vibration and absorption of infrared energy. The results of FTIR tests for Cdots by frying technique made of the leaf, stem, and root are presented in Figure 7. Based on Figure 7, the functional groups that can be identified from the samples are $\mathrm{C}=\mathrm{C}, \mathrm{C}=\mathrm{O}, \mathrm{C}-\mathrm{H}$ and $\mathrm{O}-\mathrm{H}[15,25]$. The presence of $\mathrm{C}=\mathrm{C}$ indicates the core of Cdots $[1,26]$. The $\mathrm{C}=\mathrm{O}$ bonds in the results of FTIR tests show the surface state of Cdots material [26]. The $\mathrm{C}=\mathrm{O}$ functional groups confirm the red color luminescence exhibited from the Cdots by frying technique.

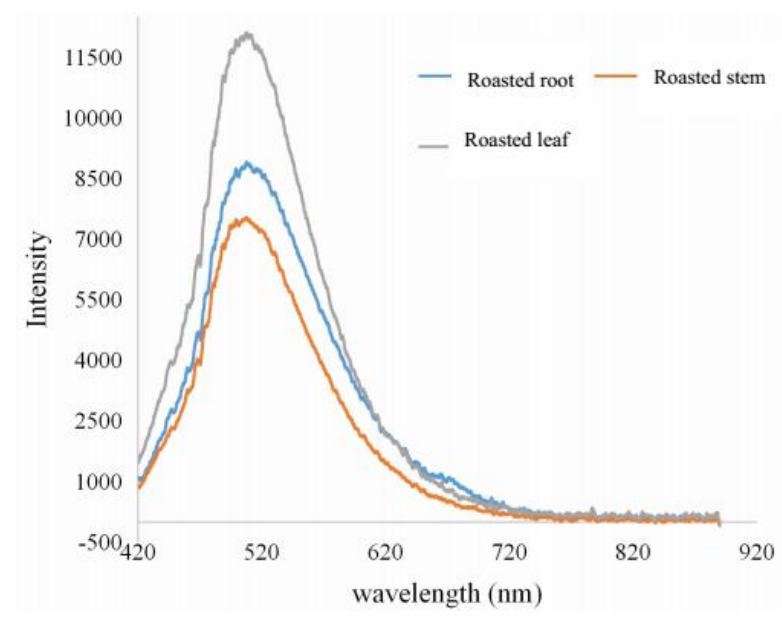

Figure 6. The Characterization Results of the Cdots by Roasting Technique using PL

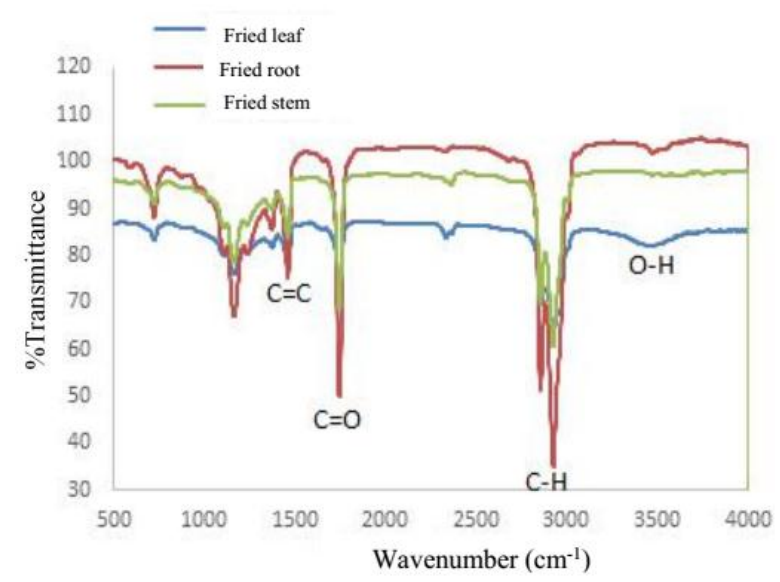

Figure 7. The Characterization Results of the Cdots by Frying Technique using FTIR 


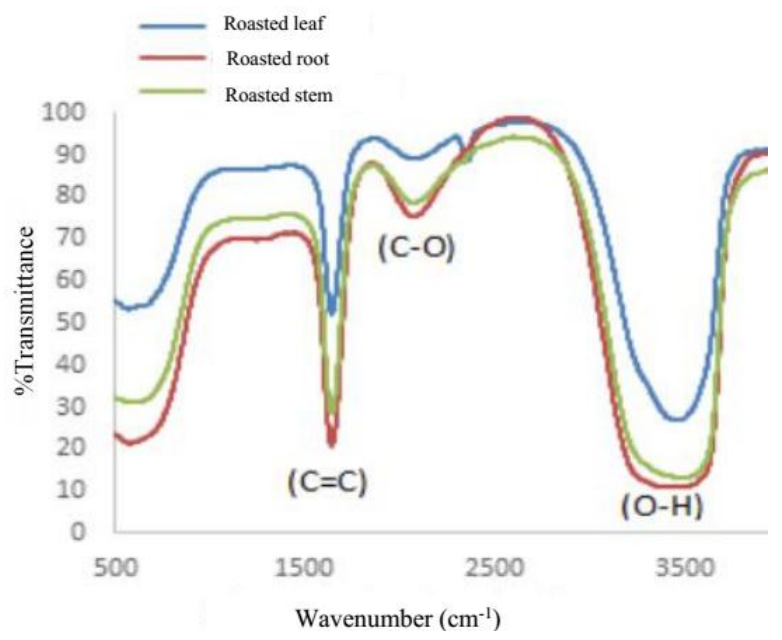

Figure 8. The Characterization Results of the

Cdots by Roasting Technique using FTIR

Figure 8 is the FTIR result of Cdots by roasting technique. The functional groups that can be identified from the samples are $\mathrm{C}=\mathrm{C}$, $\mathrm{O}-\mathrm{H}$, and $\mathrm{C}-\mathrm{O}$. The presence of these functional groups of $\mathrm{O}-\mathrm{H}, \mathrm{C}-\mathrm{O}$ and $\mathrm{C}=\mathrm{C}$ indicates successful synthesis of Cdots [27-29], and the presence of $\mathrm{C}=\mathrm{C}$ also indicates the core of Cdots $[1,26]$. In addition, there is also another functional group around $2300 \mathrm{~cm}^{-1}$ which belongs to $\mathrm{C} \equiv \mathrm{N}$. The Cdots solutions from kangkung are successfully synthesized through frying and roasting techniques containing $\mathrm{C}=\mathrm{C}$ bond that forms the core of Cdots. Moreover, the frying technique produces higher percentage of transmittance of $\mathrm{C}=\mathrm{C}$ bonds compared to the roasting technique, i.e.: $75 \%$ and $20 \%$, respectively. This means that the absorbance of the Cdots with frying technique is lower than the Cdots with roasting technique.

Based on the discussion, the frying and roasting techniques can produce Cdots with different optical properties. Both of these methods are simple, inexpensive, non-toxic, and can produce Cdots massively. Therefore, this study contributes to the many Cdots preparation with alternative procedures which gives impact the way Cdots are massively produced.

\section{CONCLUSION}

Cdots have been synthesized from kangkung plants with frying and roasting techniques. The Cdots have been characterized using UV-Vis, PL, and FTIR. Cdots samples obtained from frying and roasting techniques have different optical properties. The frying technique produces Cdots with longer wavelength at the absorbance peak in the UV-Vis test compared to the roasting technique. Moreover, the frying and roasting techniques produce different luminescence colors, namely red and green, respectively. The FTIR characterization shows the presence of $\mathrm{C}=\mathrm{C}$ and $\mathrm{C}=\mathrm{O}$ which are the core and surface state of the Cdots by frying technique, while the samples by roasting technique show only the core of Cdots. Further studies can be conducted by providing additional characterizations such as TEM or DLS which are important to further verify the existence of the Cdots material in the samples.

\section{ACKNOWLEDGMENT}

The authors would like to thank the Department of Physics Education, Faculty of Mathematics and Natural Sciences, Universitas Negeri Yogyakarta for supporting this research.

\section{REFERENCES}

[1] Dwandaru WSB, Bilqis SM, Wisnuwijaya RI, and Isnaeni. Optical Properties Comparison of Carbon Nanodots Synthesized from Commercial Granulated Sugar Using Hydrothermal Method and Microwave. Materials Research Express. 2019; 6(10): 105041. DOI: https://doi.org/10.1088/20531591/ab3952.

[2] Djojosuwit S. Azolla: Pertanian Organic san Multiguna. Yogyakarta: Kanisius; 2000.

[3] Liu XJ, Guo ML, Huang J, and Yin XY. Improved Fluorescence of Carbon Dots Prepared from Bagasse under Alkaline 
Jurnal Penelitian Fisika dan Aplikasinya (JPFA), 2019; 9(2): 123-131

Hydrothermal Conditions. BioResources. 2013; 8(2): 2537-2546. Available from:

https://ojs.cnr.ncsu.edu/index.php/BioRes/ar ticle/view/BioRes_08_22537_Liu_Fluores cence_Carbon_Dots.

[4] Bhattacharya S, Sarkar R, Chakraborty B, Porgador A, and Jelinek R. Nitric Oxide Sensing through Azo-Dye Formation on Carbon Dots. ACS Sensors. 2017; 2(8): 1215-1224. DOI:

https://doi.org/10.1021/acssensors.7b00356.

[5] Georgakilas V, Perman JA, Tuce J, and Zboril R. Broad Family of Carbon Nanoalltropes: Classification, Chemistry, and Aplications of Fullerenes, Carbon Dots Nanotubes, Graphene, Nanodiamonds, and Combined Superstructures. Chemical Reviews. 2005; 115(11): 4744-4822. DOI:

https://doi.org/10.1021/cr500304f.

[6] Bao L, Liu C, Zhang ZL, and Pang DW. Photoluminescence-Tunable Carbon Nanodots: Surface-State Energy-Gap Tuning. Advanced Materials. 2015; 27(10): 1663-1667. DOI:

http://doi.org/10.1002/adma.201405070.

[7] Niu J, Gao H, Wang L, Xin S, Zhang GY, Wang Q, Guo L, Liu W, Gao X, and Wang Y. Facile Synthesis and Optical Properties of Nitrogen-Doped Carbon Dots. New Journal of Chemistry. 2013; 38(4): 1522-1527. DOI: http://dx.doi.org/10.1039/C3NJ01068F.

[8] Bao YW, Hua XW, Li YH, Jia HR, and Wu FG. Hyperthemia Promoted Cytosolic and Nuclear Delivery of Coppercarbon Quantum Dot-Crosslinked Nanosheets: Multimodal Imaging-Guided Photothermal Cancer Therapy. ACS Applied Materials and Interfaces. 2018; 10(2): 1544-1555. DOI: https://doi.org/10.1021/acsami.7b15332.

[9] Wang L, Haoran Z, Zhou X, Liu Y, and Lei B. A Dual-Emitting Core-Shell Carbon DotSillica-Phosphor Composite for LED Plant Grow Light. RSC Advances. 2017; 7(27): 16662-16667. DOI: https://doi.org/10.1039/C7RA00227K.
[10] Suzuki K, Malfatti L, Takashi M, Carboni D, Messina F, Tokudome Y, Takemoto M, and Innocenzi P. Design of Carbon Dots Photoluminescence Through OrganoFunctional Silane Grafting for Solid-State Emitting Devices. Scientific Reports. 2017; 7: 5469. DOI:

https://doi.org/10.1038/s41598-017-05540-5.

[11] Hasan MH, Mahlia TMI, and Nur H. A Review on Energy Scenario and Sustainable Energy in Indonesia. Renewable and Sustainable Energy Reviews. 2012; 16(4): 2316-2328. DOI:

https://doi.org/10.1016/j.rser.2011.12.007.

[12] Liu H, Ye T, and Mao C. Fluorescent Carbon Nanoparticles from Candle Soot. Angewandte Chemie Internasiona Edition. 2007; 46(34): 6473-6475. DOI: https://doi.org/10.1002/anie.200701271.

[13] Dewi ARC, Aji MP, and Sulhadi. Absorbance Spectrum Carbon Nanodots (C-Dots) Daun Tembakau. Proceedings of Seminar Nasional Fisika SNF 2016. Fakultas Matematika dan Ilmu Pengetahuan Alam, Universitas Negeri Jakarta. 2016; 5: 129-134. Available from: http://journal.unj.ac.id/unj/index.php/prosidi ngsnf/article/view/4182.

[14] Fatimah S, Isnaeni I, and Tahir D. Assisted Surface-state Recombination of Orange-peel Carbon Nanodots in Various Matrices. Makara Journal of Science. 2018; 22(1): 29-34. DOI:

https://doi.org/10.7454/mss.v22i1.8301.

[15] De B and Karak N. A Green and Facile Approach for the Synthesis of Water Soluble Fluorescent Carbon Dots from Banana Juice. RSC Advances. 2013; 3(22): 8286-8290. DOI: http://dx.doi.org/10.1039/C3RA00088E.

[16] Haryoto. Bertanam Kangkung Raksasa di Pekarangan. Yogyakarta: Kanisius; 2009.

[17] Arsalani N, Nezhad-Mokhtari P, and Jabbari E. Microwave-Assisted and One-Step Synthesis of PEG Passivated Fluorescent Carbon Dots from Gelatin as an Efficient Nanocarrier for Methotrexate Delivery. 
Jurnal Penelitian Fisika dan Aplikasinya (JPFA), 2019; 9(2): 123-131

Journal Artificial Cells, Nanomedicine, and Biotechnology. 2019; 47(1): 540-547. DOI:

https://doi.org/10.1080/21691401.2018.1562 $\underline{460}$.

[18] Soni S and Loi MA. Luminescent Carbon Dots: Characteristics and Applications; 2016. Available from:

https://www.rug.n1/research/zernike/educatio n/topmasternanoscience/ns190 soni.pdf.

[19] Fadli AL. Sintesis dan Karakterisasi Nanomaterial Carbon-Dot, CarbonDot/Sulfur, dan Carbon-Dot/Silver Nanoparticle Berbahan Dasar Buah Namnam (Cynometra cauliflora L) dengan Metode Penggorengan Berbasis Minyak. Undergraduate Thesis. Unpublished. Yogyakarta: Universitas Negeri Yogyakarta; 2018.

[20] Sun YP, Zhou B, Lin Y, Wang W, Fernando, KAS, Pathak P, Meziani MJ, Harruff BA, Wang X, Wang H, Luo, PG, Yang H, Kose ME, Chen B, Veca LM, and Xie SY. Quantum-Sized Carbon Dots for Bright and Colorful Photoluminescence. Journal of the American Chemical Society. 2006; 128(24): 7756-7757. DOI:

https://doi.org/10.1021/ja062677d.

[21] Mewada A, Vishwakarma R, Patil B, Phadke C, Kalita G, Sharon M, and Sharon M. NonBlinking Dendritic Crystal from C-Dots Solution. Carbon Letters. 2015; 16(3): 211214. DOI:

http://dx.doi.org/10.5714/CL.2015.16.3.211.

[22] Li L, Zhang R, Lu C, Sun J, Wang L, Qu B, Li T, Liu Y, and Li S. In Situ Synthesis of NIR-Light Emitting Carbon Dots Derived from Spinach for Bio-Imaging Applications. Journal of Materials Chemistry B. 2017; 5(35): 7328-7334. DOI:

http://doi.org/10.1039/C7TB00634A.

[23] Wu H, Zhou F, Zhu Z, and Chen Y. On the Distance Spectrum Assignment in Elastic Optical Networks. Journal IEEE/ACM Transactions on Networking (TON). 2017; 25(4): 2391-2404. DOI:
http://dx.doi.org/10.1109/TNET.2017.26856 $\underline{88}$.

[24] Wang L, Zhu SJ, Wang HY, Qu SN, Zhang YL, Zhang JH, and Sun HB. Common Origin of Green Luminescence in Carbon Nanodots and Graphene Quantum Dots. ACS Nano. 2014; 8(3): 2541-2547. DOI:

https://doi.org/10.1021/nn500368m.

[25] Himaja AL, Karthik PS, and Singh SP. Carbon Dots: The Newest Member of the Carbon Nanomaterials Family. The Chemical Record. 2015; 15(3): 595-615. DOI: http://doi.org/10.1002/tcr.201402090.

[26] Zhang J, Wang H, Xiao Y, Tang J, Liang C, Li F, Dong H, and Xu W. A Simple Approach for Synthesizing of Fluorescent Carbon Quantum Dots from Tofu Wastewater. Nanoscale Research Letters. 2017; 12: 611. DOI: https://doi.org/10.1186/s11671-0172369-1.

[27] Campos BB, Contreras-Caceres R, Bandosz TJ, Jimenez-Jimenez J, Rodriguez-Castellon E, Esteves da Silva JCG, and Algarra M. Carbon Dots as Fluorescent Sensor for Detection of Explosive Nitrocompounds. Carbon. 2016; 106: 171-178. DOI: https://doi.org/10.1016/j.carbon.2016.05.030.

[28] V R, Gujar V, Pathan H, Islam S, Tawre M, Pardesi K, Santra MK, and Ottoor D. Bioimaging Applications of Carbon dots (C. dots) and its Cystamine Functionalization for the Sensitive Detection of $\mathrm{Cr}(\mathrm{VI})$ in Aqueous Samples. Journal of Fluorescence. 2019; 29: 1381-1392. DOI: https://doi.org/10.1007/s10895-019-024483.

[29] Shukla D, Pandey FP, Kumari P, Basu N, Tiwari MK, Lahiri J, and Parmar AS. LabelFree Fluorometric Detection of Adulterant Malachite Green Using Carbon Dots Derived from the Medicinal Plant Source Ocimum tenuiflorum. Chemistry Select. 2019; 4(17): 4839-4847. DOI:

http://dx.doi.org/10.1002/slct.201900530. 